\title{
Structural changes utilization agricultural land and plant production: the case northeastern Montenegro
}

\author{
Goran Rajović $^{1, *}$, Jelisavka Bulatović ${ }^{2, * *}$ \\ ${ }^{1}$ Street Vojvode Stepe 252, Belgrade, Serbia \\ Phone: 0038161/19-24-850 \\ ${ }^{2}$ College of Textile Design, Technology and Management, \\ Street Starine Novaka 20, Belgrade, Serbia \\ Phone: 003861/3082651
}

*,**E-mail address: dkgoran.rajovic@gmail.com , jelisavka.bulatovic@gmail.com

\begin{abstract}
Among the growth, potential of northeastern Montenegro primary importance is agricultural land. The structure of agricultural land according to the use, by applying the method of alternating splitter in the system $6 / 6$, we found type of secondary representation meadows, with a greater share of pasture and arable land $\mathrm{P}_{3} \mathrm{~L}_{2} \mathrm{O}_{1}$ participation. Type the equal participation of vegetables, animal fodder and grain products and share uncultivated arable land $\mathrm{Po}_{2} \mathrm{Sk}_{2} \breve{Z}_{1} \mathrm{No}_{1}$, characterized by the use of the structure of arable land. Judging by the size of the total area planted, production volumes, as well as other indicators, crop production northeastern Montenegro mainly serves to meet the needs of the household. A smaller part of are intended market.
\end{abstract}

Keywords: Northeastern Montenegro; agricultural areas; structural changes in crop production

\section{INTRODUCTION}

Northeastern Montenegro is a geographical unit which comprises $10.8 \%$ of the total area of Montenegro $\left(13.812 \mathrm{~km}^{2}\right)$, that is, living in the territory, $8.12 \%$ of the population compared to the total population of Montenegro in 2003 (673.094). Territory includes three municipalities: Plav, Andrijevica and Berane, with an area of $1.486 \mathrm{~km}^{2}$, which is by the census of 2003 year, 54.658 people lived or $36.8 \mathrm{in} / \mathrm{km}^{2}$ (Rajović and Bulatović, 2012a).

Types of agricultural land and its qualitative characteristics are favorable for the development of agriculture northeastern Montenegro. However, survey analysis that follows shows that agriculture and crop production in the region is not in conformity with all available natural and social conditions. Discrepancy between available resources and modern crop production is determined by the global economic policy, tradition, demographics, economic structure and market.

Specifically, the northeastern territory of Montenegro, insufficient attention was paid to the problems of agricultural development, especially the choice of the optimal structure of production. Also, the present method of management (small plots, tillage outdated, uncoordinated structure of production), is a function of agricultural development. Greater 
appreciation of agriculture as a primary activity, which can be exploited comparative advantages of the region (see Rajović, 2013).

The results of this survey were used to work the authors consider the structure of agriculture, and within them, and arable land in the region and separate directions exploitation of agricultural and arable land. Crop production in northeastern Montenegro, emerges as the ultimate effect already outlined the structure of agricultural land utilization.

This article refers only to the portion of the truth of important issues related to agriculture northeastern Montenegro, while other studies, such as those that indicate the typological characteristics of agriculture: current owner and socio-organizational-technical, is of great importance from the viewpoint of scientific knowledge for the proper routing of all social actions and measures of agricultural policy. Of course, they are not the subject of this paper.

\section{RESEARCH METHODOLOGY}

This paper has several objectives. First of all, to determine are structure of agricultural land in the period 1964-2005. The next goal is to show structural changes in crop production. In the end, the goal of the research is based on the spatial differentiation of structural trends of agricultural land. The research methodology is primarily based on an analysis of existing agrogeographical literature, as well as data on agricultural land and crop production, given out by the Statistical Office of Montenegro.

The literature include: agricultural monographs, proceedings, books and statistics. Were studied and written sources on the internet. In the context of agro-geographic study of agriculture, we apply the method to a system of alternating dividers 6/6, developed at the Institute of Geography of the Polish Academy of Sciences (Kostrovicki, 1969 and 1970).

This method determines the orientation of the agricultural territory studied (Jaćimović, 1976). The literature review and the terms under the agricultural structure and procedure for applying the method, "kolejnih ilorazow" (alternate splitter), and provides Tyszkiewicz (1978).

The scientific explanation of the concepts in this study, we applied two methods are used: analytic and synthetic. Analytical methods are considered some of the dimensions of the research topic, and a synthetic whole, the interconnections between the case and suggested measures that derive there from.

\section{ANALYSIS AND DISCUSSION}

Agricultural land is an important part of the natural wealth of the region.

The structure of land use in certain categories is of special importance because it is the result of development and intensity of agriculture and it expresses the degree depending territorial conditions for the development of certain types of agricultural production (Todorović, 1985).

In Table 1 we present the agricultural land use categories. 
Table 1. Agricultural land use by categories in northeastern Montenegro 1964 and 2005.

\begin{tabular}{|c|c|c|c|c|}
\hline Year & \multicolumn{2}{|c|}{1964} & \multicolumn{2}{c|}{2005} \\
\hline Category land & in ha & $\%$ & in ha & $\%$ \\
\hline Agricultural areas & 70.478 & 100 & 67.379 & 100 \\
\hline $\begin{array}{c}\text { Fields and } \\
\text { gardens }\end{array}$ & 8.440 & 11,98 & 6.722 & 9,98 \\
\hline Orchards & 1.826 & 2,59 & 2.334 & 3,46 \\
\hline Meadows & 19.926 & 28,27 & 20.502 & 30,43 \\
\hline Grasslands & 40.286 & 57,16 & 37.821 & 56,13 \\
\hline
\end{tabular}

Source: Statistical Office of Montenegro (1966 and 2006), Agricultural Census 1964 and 2005, data calculations by the author

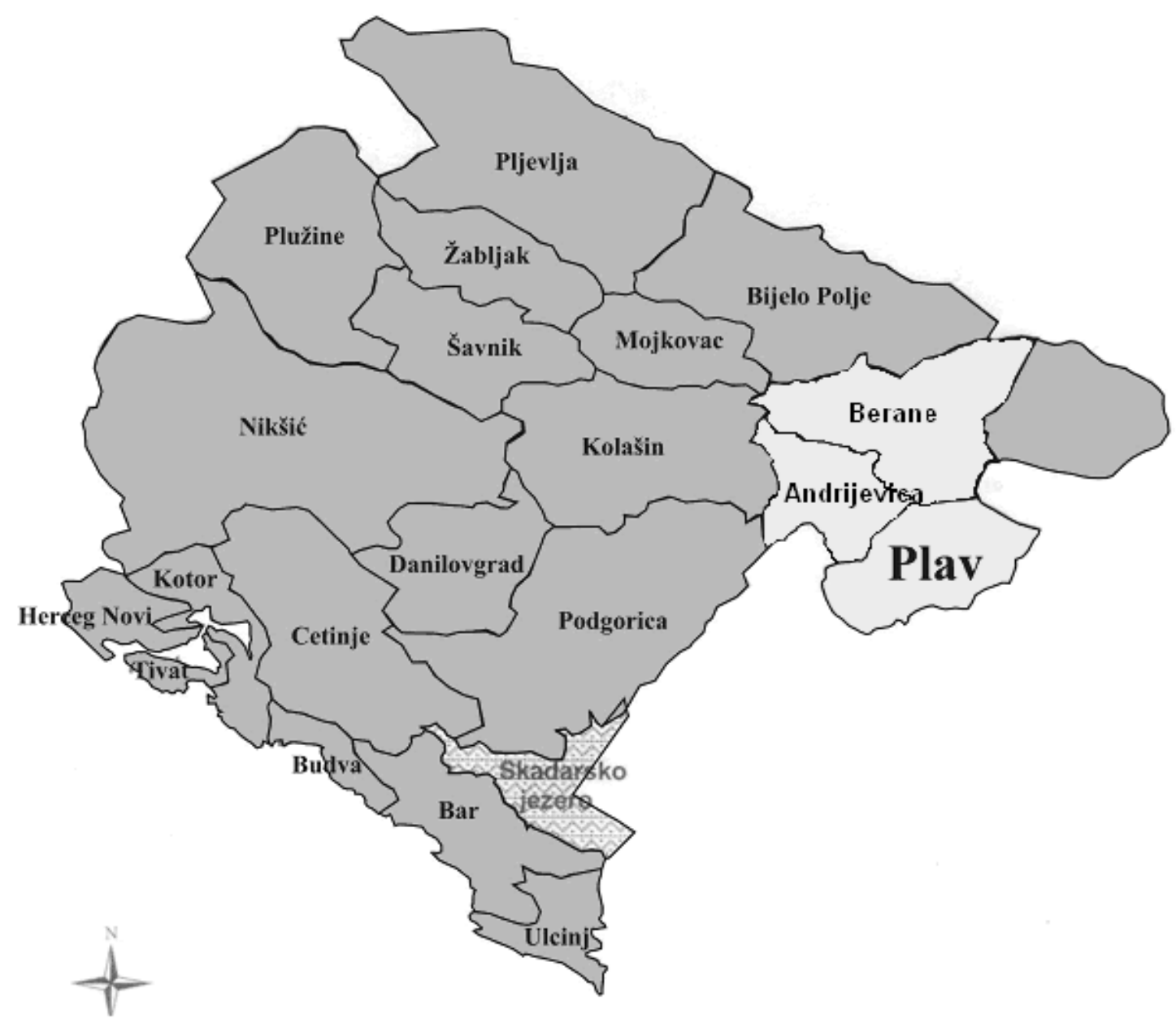

Figure 1. the geographical position of the municipality Berane, Andrijevica and Plav (Northeastern Montenegro) on the map of Montenegro. (Source: Regional Business Centre Berane (2004), Rajović and Bulatović (2012b). 
In the period 1964-2005 in the agricultural land of the region there has been a change in the manner of utilization to reduce the area under fields and gardens and pastures (Table 1). In contrast are increased area under orchards and meadows.

Arable land in the period was reduced from 8.440 ha in 1.964 to 6772 ha in 2005, up to 1.668 ha. Area under orchards are creased in the same period from 1826 ha to 2334 ha or 508 ha. Surface of meadows, recorded a slight increase from 19.926 ha to 20.502 ha or 576 ha. Land pastures in the period 1964- 2005 decreased from 40.286 ha to 37.821 ha or 2.465 ha. Given the state of mind of the livestock and the degree of degradation of pastures, it is logical to expect a further decline in this category of land.

Applying the method of alternating splitter in the system $6 / 6$, we have found in northeastern Montenegro in 2005, following the direction of agricultural land:

$\mathrm{P}_{3} \mathrm{~L}_{2} \mathrm{O}_{1}$-Type of secondary representation meadows, pastures with greater involvement and participation of the arable land ${ }^{1}$.

Structural changes have taken place since 1964, does not alter the character of the agriculture of northeastern Montenegro. By method of alternating splitter in the system $6 / 6$, we get the identical type of exploitation of agricultural land.

The total area under maize fields and gardens accounts for $13.84 \%$, or $1.38 \%$ of the total agricultural area. Wheat is to $2.28 \%$ or $0.22 \%$. Rye in are with $0.25 \%$ and barley in $0.40 \%$ of the total arable land and gardens, or rye with $0.02 \%$, barley at $0.04 \%$ of the total agricultural area. In 2005, the area of fodder production totaled $30.29 \%$ of the total arable land, or $3.02 \%$ of the total agricultural area. Sown area of alfalfa $4.75 \%$ compared to arable or $0.47 \%$ of total agricultural land. In the same period, other cattle fodder (clover, vetch, a mixture of grasses ...) encompassed an area of $25.55 \%$ compared to arable or $2.54 \%$ of total agricultural land. Areas under natural grasslands amount 58.323 ha.

The surface of 20.502 ha of meadows, 37.821 ha of pastures or participate in the total agricultural area with $30.42 \%$, or $56.13 \%$. Total area under vegetable crops in 2005 amounted to $39.87 \%$ of the total arable land, or $3.97 \%$ of agricultural land. Potato is the official statistics dominant vegetable crop. Under these vegetable crops, there was $29.90 \%$ of sown area to total arable or $2.98 \%$ of agricultural land. The total area under beans was $2.05 \%$ of the total arable or $0.20 \%$ of the total agricultural area. Area under other vegetables (onion, cabbage, cucumbers, pumpkins, peas ....) included the $7.91 \%$ of the total arable or $0.78 \%$ of the total agricultural area.

Arable land is the most important category of land. However, statistics show that spontaneously abandoned arable land or planning translated into other categories of land, or alienating for non-agricultural purposes. Threaded with a reduction in the area under arable land, there comes a change in the structure of its use.

The use of the structure of the arable land in the period $1964-2005$, noted the positive changes in the direction of increasing the area under vegetable crops (1.305 ha $-2.680 \mathrm{ha})$, cattle fodder ( 759 ha -2.036 ha).

Adverse changes in the structure of use are contained in the fact that the area under cereals decreased (6.350 ha - $1.127 \mathrm{ha}$ ), under industrial plants canceled (26 ha -0$)$, and increase the area under fallow land (for 879 ha). The increase has been causing by the phenomenon of elderly households that are not able to cultivate their property.

\footnotetext{
${ }^{1}$ The variables and their symbols used in the formula: O - arable land, V- Orchards, L- Meadows, P- Pastures.
} 
Table 2. Utilization of agricultural land in northeastern Montenegro 2005.

\begin{tabular}{|c|c|c|c|c|}
\hline \multirow{2}{*}{$\begin{array}{c}\text { Categories of land and } \\
\text { culture }\end{array}$} & ha & \multicolumn{3}{|c|}{ \% } \\
\cline { 3 - 5 } & & $\begin{array}{c}\text { Participation } \\
\text { in group }\end{array}$ & $\begin{array}{c}\text { Fields and } \\
\text { gardens }\end{array}$ & Farmer surface \\
\hline I. Fields and gardens & 6.722 & & 100 & 9,97 \\
\hline A. Grains & 1.127 & 100 & 16,76 & 1,67 \\
\hline Corn & 930 & 82,52 & 13,84 & 1,38 \\
\hline Wheat & 153 & 13,58 & 2,28 & 0,22 \\
\hline Rye & 17 & 1,51 & 0,25 & 0,02 \\
\hline Barley & 27 & 2,39 & 0,40 & 0,04 \\
\hline B. Vegetables & 2.680 & 100 & 39,87 & 3,97 \\
\hline Potato & 2.010 & 75,0 & 29,90 & 2,98 \\
\hline Beans & 138 & 5,15 & 2,05 & 0,20 \\
\hline Other vegetables & 532 & 19,85 & 7,91 & 0,78 \\
\hline C. Fodder crops & 2.036 & 100 & 30,29 & 3,02 \\
\hline Alfalfa & 319 & 15,67 & 4,75 & 0,47 \\
\hline Other cattle fodder & 1.712 & 84,33 & 25,54 & 2,54 \\
\hline D. Fallow land & 879 & 100 & 13,08 & 1,30 \\
\hline II. Orchards & 2.334 & 100 & & 3,46 \\
\hline III. Meadows & 20.502 & 100 & & 30,42 \\
\hline IV. Grasslands & 37.821 & 100 & & 56,13 \\
\hline TOTAL & 67.379 & & & 100 \\
\hline Sodinn & & & \\
\hline Stann & & & \\
\hline
\end{tabular}

Source: Statistical Office of Montenegro (2006), Agricultural Census 2005, data calculations by the author

Table 3. Sowing structure arable area northeast of Montenegro in 1964 and 2005.

\begin{tabular}{|c|c|c|c|c|}
\hline Year & \multicolumn{2}{|c|}{$\mathbf{1 9 6 4}$} & \multicolumn{2}{c|}{$\mathbf{2 0 0 5}$} \\
\hline Category land & ha & $\%$ & ha & $\%$ \\
\hline Fields and gardens & 8.840 & 100 & 6.722 & 100 \\
\hline Grains & 6.350 & 75,24 & 1.127 & 16,77 \\
\hline Industrial Crops & 26 & 0,31 & - & - \\
\hline Vegetables & 1.305 & 15,46 & 2.680 & 39,87 \\
\hline Fodder crops & 759 & 8,89 & 2.036 & 30,29 \\
\hline $\begin{array}{c}\text { Uncultivated arable } \\
\text { land }\end{array}$ & - & & 879 & 13,08 \\
\hline
\end{tabular}

Source: Statistical Office of Montenegro (1966 and 2006), Agricultural Census 1964 and 2005, data calculations by the author 
To get an adequate picture of the structure of arable land in northeastern Montenegro and here we apply the method of alternating dividers 6/6 and found in 2005 (in the absence of statistical data for uncultivated arable land in 1964. We did not access the application of the methods of alternate splitter because the result would not be appropriate), use the following direction arable areas:

\section{$\operatorname{Po}_{2} S_{2} \check{Z}_{1} N_{01}-$ Type the equal participation of vegetables and livestock fodder and grain products and share uncultivated arable land ${ }^{2}$.}

Total agricultural - geographical changes in northeastern Montenegro are extremely high just under the influence of depopulation (see Rajović, 2009 and 2011a). "Permanent emigrations of young people in other areas that are affected by are physical volume of agricultural production more than halved" (Jaćimović and Šećibović, 1992). This especially said in crop production problems. Data that show exactly reflect the many changes that have occurred in the last four decades studied agriculture in the region.

Crop production in northeastern Montenegro, emerges as the ultimate effect of the above said land use structures, methods and land use directions in it. Size of plant production, greatly depends on the climate and soil conditions, but also the use of cultural practices, modern machinery and mineral fertilizers (see Rajović, 2007; 2009b; 2011b; 2011c). Judging by the size of the total area planted, production volumes, as well as other indicators of crop production mainly serves to meet the needs of the household. A smaller part of are intended market. Here are the following examples to support this.

Arable land been mostly used for sowing harvest. Thus, in comparison to 1964 in northeastern Montenegro was reduced sown area, from 8.440 ha to 6.772 ha in 2005 . Of these, the grain accounted for 6.350 ha in 1964 and 1127 ha in 2005. In area where corn is was grown dominant grain grown in region. Since the sixties of the twentieth century years, corn acreage in this grain is constantly decreasing. Compared to 1964, the area under maize decreased by 2.265 ha. Maize production in northeastern Montenegro in the period of 1964 - 2005 been reduced from 6.034 tons to 1.452 tones. Thus, maize is low and primarily determined by the amount of rainfall during the growing season, especially the government deficit in July and August, when the corn is in the process of maturing grain. The average corn yield per hectare in the region amounted to 1.6 tons in 2005 . Thus, stable corn yields may have been providing with irrigation of arable land. However, if one takes into account the temporal and spatial distribution of water suitable for irrigation is insufficient, and that they mainly used for irrigation of vegetable crops, then small amounts of water remain so available for irrigation area under maize. Wheat is the most abundant plant other crops in the region. Compared to 1964, the area under wheat been reduced to 1.533 ha. Although the reduced area under wheat, the average yield of wheat have been increasing from $2.9 \mathrm{t} /$ ha in 1964 to $2.5 \mathrm{t} /$ ha in 2005 . Despite cultivars of use and considerably modern agricultural practices in the basin Berane, wheat yields significantly determined by the agro-climatic conditions. However, the cultivation of wheat in the region decreases significantly due, in large costs of its production and labor shortages, and because of the simple reason that it is cheaper to buy bread in the shops than "To look at the wheat field and worry about what will be her next race and the effort and expense"(Jaćimović,1971). The grain structure similar changes have occurred in the production of wheat and barley. Thus, rye harvested area reduced from 53 ha in 1964 to 17 ha in 2005. The drastic decline is present in barley, harvested in 1964 when the area of 68 ha in 1964 reduced to 27 ha in 2005 . Both cultures tolerate cold, drought, and the government, and succeed

\footnotetext{
${ }^{2}$ The variables and their symbols used in the formula: Ž-grain, I-Industrial Crops, Po-Vegetables, Sk-cattlefodder, No-uncultivated arable land
} 
where other cultures would be difficult to adapt. In addition, the production of these crops been reduced, as are grown for their own use in small spaces and less fertile soils. Average yields of rye remained in 2005 at the level of 1964 , when they amounted to $1.0 \mathrm{t} / \mathrm{ha}$. While the average barley yields increased from $1.0 \mathrm{t} / \mathrm{ha}$ in 1964 to $1.5 \mathrm{t} /$ ha in 2005 .

Industrial plants have decreased from 26 ha in 1964 to the cessation of production in 2005. Greatest importance in are diet of cattle in the region, despite changes in the way of growing a fodder with natural grasslands and arable land under forage crops. In the period 1964 - 2005, for the production of fodder, increased from 759 ha in 1964 to 2036 ha in 2005, up from 1.277 ha. Are surfaces of alfalfa with 559 ha to 319 ha? In are same period, increased the area under other livestock forage crops (clover, vetch, a mixture of grass ....) from 200 ha to 532 ha. Despite the decrease in surface area, alfalfa also stagnated.

The main reason for are decline in average yields (1964, 5.0 $\mathrm{t} / \mathrm{ha} ; 2005.4,4 \mathrm{t} / \mathrm{ha}$.) Is a poor use of agricultural technology, unmatched selection and variety of protective measures? The structure of the grassland area in the period 1964 - 2005 there was a change. Areas under natural grasslands have been reduced (in 1964 amounted to 60.212 ha and 58.323 ha in 2005).

The area of meadows increased by 576 ha (from 19.926 ha in 1964 to 20.502 ha in 2005), while the area under pastures reduction for 2465 ha (40.286 ha in the 1964 to 37.821 ha in 2005). Average yields of hay in the period $1964-2005$ the fields were increased from $1.5 \mathrm{t} /$ ha to $2.0 \mathrm{t} / \mathrm{ha}$, while in the pasture remained the same $0.4 \mathrm{t} / \mathrm{ha}$.

Table 4. Production and yield of field crops and fodder plants in northeastern Montenegro 1964 and 2005.

\begin{tabular}{|c|c|c|c|c|}
\hline \multirow{2}{*}{$\begin{array}{c}\text { Crops and fodder } \\
\text { crops }\end{array}$} & \multicolumn{2}{|c|}{1964} & \multicolumn{2}{c|}{ 2005 } \\
\cline { 2 - 5 } & Production in tons & Yield in t /ha & $\begin{array}{c}\text { Production in } \\
\text { tons }\end{array}$ & Yield in t /ha \\
\hline Corn & 6.034 & 1,9 & 1.452 & 1,6 \\
\hline Wheat & 2.551 & 1,5 & 383 & 2,5 \\
\hline Rye & 50 & 0,9 & 17 & 1,0 \\
\hline Barley & 686 & 1,0 & 40 & 1,5 \\
\hline Potato & 5.762 & 5,2 & 10.019 & 5,0 \\
\hline Beans & 89 & - & 377 & 3,4 \\
\hline Alfalfa & 2.806 & 5,0 & 1.399 & 4,4 \\
\hline $\begin{array}{c}\text { Yields from the } \\
\text { meadow }\end{array}$ & 29.692 & 1,5 & 40.906 & 2,0 \\
\hline Yields of pasture & 15.066 & 0,4 & 14.013 & 0,4 \\
\hline
\end{tabular}

Source: Statistical Office of Montenegro (1966 and 2006), Census of Agriculture (the relevant year), the calculation of data by the author

Thus, the natural grasslands give small yields because the greater part of the surface being applied cultural practices, such as tillage, fertilization, weed control.... In addition, is fluctuation of the total biomass production in the period and affect climate conditions. "The production and quality of feed on natural grasslands greatly influences are way of using food"(Popović, 1986).

For example, late mowing of meadows and pastures without the use of power system allows the smooth reproduction of weeds and deteriorating quality of the obtained biomass. 
"By increasing are yield of natural grasslands amelioration, released to a substantial portion of arable land for are production of a second" (Spasojević, 1998).

Vegetable farming is one of the most intensive field crop productions, since, for the effort and the realized production. Total area under vegetable crops in is region in the period 1964 2005 , increased from 1.305 ha to 2.680 ha or 936 . Potato is the official statistics is the dominant vegetable crop. Under these vegetable crops there were 1.112 ha in 1964 and 2.010 ha in 2005.

The main problem of are potato stable, despite the use of quality planting materials (the Dutch seed potato and homemade potato), the unfavorable rainfall patterns in the second half of the growing season. Average potato yields per unit area are varied, ranging from $5.2 \mathrm{t} / \mathrm{ha}$ in 1964 to $2.1 \mathrm{t} / \mathrm{ha}$ in 2005 . Surveys made with potato producers indicate that the yield is much higher than the official statistics $(7-10 \mathrm{t} / \mathrm{ha})$. The yields of early varieties of potatoes per hectare are much lower, because he put on the market before the biological maturity (young potatoes). Production is of early varieties of potatoes stand out in the village of Lima valley: Navotina, Lužac, Dapsiće and Zagorje. Beans grow best in loose and fertile soil, particularly at the upper alluvial plains.

According to the 1964 census beans were planted on 21 ha and 138 ha in 2005. Beans are traditionally sown as intercrop maize, but the penetration of sunlight hinders its development. It has caused the so-called bean planting "pure culture." Total production of beans in 1964 was 89 tons in $2005-377$ tons.

The most widespread varieties are the local white and yellow beans, and U.S. finegrained varieties of beans. The average yield of beans in the region in 2005 amounted to $3.4 \mathrm{t}$ / ha. So bean yields, determined by the agro-climatic conditions. Other vegetables (onion, cabbage, cucumbers, pumpkins, peas ......) are very widespread in the region. Area planted to these kinds of vegetables increased from 174 ha in 1964 to 532 ha in 2005.

Official statistics do not provide details of average yields and production. However, the introduction of new varieties, improved agricultural technology and organization of production, planted area under "other vegetables" may increase because there are natural environmental conditions. Qualitative improvement of vegetables should go in favor of some herbaceous and of root crops. Recent achievements in introducing among other vegetable planting vegetables so called. High beams that will ensure water - air mode, the possibility of early sowing, sowing warmer layer, complete care of plants, irrigation and the application of mechanization (Grčić and Grčić, 2002).

In northeastern Montenegro expanse of hilly terrain, are a mosaic of soil types, a moderate continental climate provides favorable conditions for all types of central European fruit. On the development of horticulture in the region, significantly affect the cells of fruit growers for fruit trees (Berane). Area under orchards in the period 1964 - 2005 increased from 1.826 ha to 2.334 ha or 508 ha.

Plums are the number of trees and total production of fruit dominant culture of the region. Number of fruit trees grew from 403.020 in 1991 to 410.300 in 2005 year. Increasing the number of trees is determined by creating orchards on the outskirts of the mountain, the replacement of local varieties (cultivar), other domestic (Beauty of Čačak, wounds Čačak) and foreign varieties (Stanley). The total production and yield per tree in the front row are determined agro-climatic conditions. The basic requirement is limiting late (spring) frost.

Average are yield in 2005 amounted to $9 \mathrm{~kg}$ per tree native. Total production of plums in the region amounted to 3.687 tons. "If the tendency of higher yields and production generated support required processing capacity and better organized plum buying, choice and selection of better varieties, modern treatment and protection from diseases and pests. This would also 
encourage faster are reconstruction plum orchard" (Grčić and Grčić, 2002). Total number of apple trees in 1964 was 129.515, in 2005 - 62.020 which is less than 49,065 trees.

In this period there has been a renewal of plant material, but came to the fore and disease in apples: "Erwinia amylovora", "Venturia inaequalis", "Podosphaera leucotricha", "Monilia fructigena", "Nectria galligena", "Phytophthora cactorum". Apple production in the period 1991-2005 slightly increased from 727 tons to 731 tons.

The general level of apple production been characterized by the application of a modest cultural practices varied assortment, resulting in uneven and yield per tree, which in 1991 amounted to $6 \mathrm{~kg}$ per tree, native, in 2005 the $12 \mathrm{~kg}$. Apple's are range of versatile than other types of fruit.

Noble varieties - Delicious and Jonathan are somewhat suppressed by acidic sweet and sour and I dared. Are grown and indigenous varieties like pastry, "budimska", "krstovača", "petrovača "......Pear by the number of trees is the third in the region.

In are period 1991 - 2005 the number of pear trees increased from 22.600 to 29.620. Pear production in 1991 amounted to 106 tons, and 424 tons in 2005. Are average yield of pears in the period ranging from $5-14 \mathrm{~kg}$ per tree native.

Table 5. Number of trees, production and yield of certain fruits in northeastern Montenegro 1991 and 2005.

\begin{tabular}{|c|c|c|c|}
\hline \multicolumn{4}{|c|}{1991} \\
\hline Type of fruit & Number of trees & Production in tons & The yields tree in kg \\
\hline Apples & 129.515 & 727 & 6 \\
\hline Pears & 22.600 & 106 & 5 \\
\hline Plums & 403.020 & 987 & 2 \\
\hline \multicolumn{4}{|c|}{2005.} \\
\hline Apples & 62.020 & 731 & 12 \\
\hline Pears & 29.620 & 424 & 14 \\
\hline Plums & 410.300 & 3.687 & 9 \\
\hline
\end{tabular}

Source: Statistical Office of Montenegro (1991 and 2006), Census of Agriculture (the relevant year), the calculation of data by the author.

Uncertainty is unprofitable and other factors in crop production in the period 1964-2005 years completely changed the earlier views on the development of certain branches of agriculture. It shows data of crop production, which is understandable if we take into account the overall policy agro complex region.

These data are the best illustration of the state of crop production. This low productivity is certainly the result of a recurring stress the fact - the abandonment of agricultural production and the now apparent abandonment of arable land, then the low yield of food plants, vegetable plants insufficient production, insufficient fund in fruit, whose production is also low. 


\section{CONCLUSION}

Our research records, based on similar studies Kalezić (1976) and Todorović (2006), pointed to the fore several important conclusions:

1. In the period 1964-2005 in the agricultural land northeast of Montenegro there is a change of land utilization to reduce the area under fields and gardens and pastures. In contrast been increased area under orchards and meadows.

2. The structure of the arable land use, one notes a change in the direction of increasing the area under vegetable crop and livestock fodder. Adverse changes in the structure of use are contained in the fact that the area under cereals decreased, abolished under industrial plants and increase the area under fallow land.

3. Applying the method of agro-geographical study of the typology of Agriculture (alternate method splitter in the system 6/6), we selected types (directions) utilization of agricultural land in the region. Separate types (directions) of agricultural land indicate that agriculture northeastern Montenegro not complied with all available natural and social conditions. Discrepancy between available resources and modern agricultural production has been determining by the global economic policy, tradition, demographics, economic structure and market.

4. Rational management of agricultural land, many factors make it difficult. These are the problems of fragmentation of private property, the permanent loss of agricultural land due to urbanization, undefined state land management, significant proportion of untreated and neglected productive land....( see Rajović and Bulatović, 2013 a). Agriculture in the region must been based on the development of rural areas, as well as more functional / integrated production, social and cultural space and strengthening the economic power farms, and their involvement in the market economy, with the right mix of factors such as natural resources, demographics, transportation infrastructure connectivity(see Rajović and Bulatović, 2013 b).

5. The use of agricultural land should gradually decline, reject conventional, and to predict and promote organic farming, that is oriented primarily to the production of "health food" products as a specific region, with the aim of promoting the system based on geographic origin, methods of production, tradition and environmental guarantees. Now the European geographical area about the shift from "quantity - been orienting agriculture (yield)" to "quality has been oriented agriculture" (food and environment).

\section{References}

[1] Rajović G., Bulatović J., Journal for Geography 7 (1) (2012) 49-68, (2012a).

[2] Rajović G., Journal of Agriculture and Sustainability 2 (1) (2013) 22-42, (2013a)

[3] Kostrovicki I., Przeglad Geograficzny XLI (4) (1969) 599-621.

[4] Kostrovicki I., Geographia Polonica 18 (1970) 93.

[5] Jaćimović B., Proceedings of Institute of Geography Faculty of Science XXIII (1976) 94-99.

[6] Tyszkiewicz W., Przemiany struktury przestrzennej rolnictwa Polski 1950-1970, Prace Geograficzne, 126, Ig and PZ PAN, 1978, pp.15-54. 
[7] Todorović M., Development of modern agricultural complex in Gornji Milanovac, Proceedings of the Geographic Institute "Jovan Cvijić, Serbian Academy of Sciences and Arts 37 (1985) 41-78.

[8] Statistical Office of Montenegro, Census agriculture 1964 year, Podgorica, 1966.

[9] Statistical Office of Montenegro, Census agriculture 2005year, Podgorica, 2006.

[10] Regional Business Centre Berane, Profile municipality of Berane, Available from: http://www.nasme.me (24.01 2013).

[11] Rajović G., Bulatović J., Russian Journal of Agricultural and Socio - Economic Sciences 9(9) (2012) 3-20, (2012 b).

[12] Jaćimović B., Šaćibović R., Journal of Geography Faculty of Natural Sciences and Mathematics Sciences 40 (1992) 77-82.

[13] Rajović G., Journal Economics 55(6) (2009) 33-44, (2009a).

[14] Rajović G., Annals of the University of Oradea - geography series 21(1) (2011) 105-117, (2011a).

[15] Rajović G., Journal Economics 53(3-4) (2007) 58-67.

[16] Rajović G., Journal Industry 37(4) (2009) 15-27, (2009b).

[17] Rajović G., Journal Economics 57 (2) (2011) 62-72, (2011b).

[18] Rajović G., Journal Industry 39(3) (2011) 15-27, (2011c).

[19] Jaćimović B., Geography Institute Serbian Academy of Arts and Sciences Proceedings 17 (1971) 217-240.

[20] Popović M., Yugoslav Review 6 (1986) 307-314.

[21] Spasojević M., The economic geography of the Federal Republic of Yugoslavia, Faculty of Economics University of Niš, 1998, pp.143-149.

[22] Grčić M., Grčić Lj., Mačva, Šabačka Posavina and Pocerina, Faculty of Geography University of Belgrade, Belgrade, 2002, pp. 456-493.

[23] Kalezić Ž., Structural changes in the Montenegrin settlement in the twentieth century, "Print Victory", Titograd, 1976, pp. 130-134.

[24] Todorović M., Agrarian geographic data Municipal Ljig, Proceedings Geographical Institute "Jovan Cvijić" Serbian Academy of Arts and Sciences, 55 (2006) 121-141.

[25] Rajović G., Bulatović J., Journal of Agriculture and Sustainability 3(2) (2013) 165-182, (2013a).

[26] Rajović G., Bulatović J., Journal of Agriculture and Sustainability 2(2) (2013) 178-195, (2013b). 